\title{
Farmers' Adaptive Capacity to Climate Change in Africa: Small-Scale Farmers in Cameroon
}

\author{
Nyong Princely Awazi, Martin Ngankam Tchamba, \\ Lucie Felicite Temgoua, and Marie-Louise Tientcheu-Avana
}

\section{Contents}

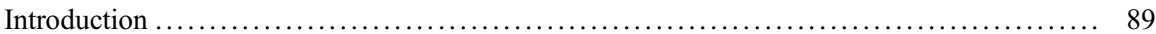

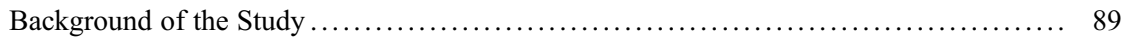

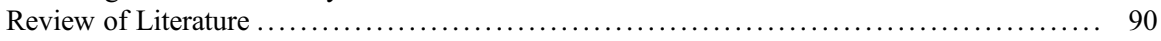

Perceptions of Climate Change by Small-Scale Farmers in Africa ................... 90

Adverse Effects of Climate Change on Africa's Small-Scale Farmers .................. 91

Drivers of Small-Scale Farmers' Vulnerability to Climate Change in Africa ............ 92

Adaptation Options Implemented by Small-Scale Farmers in Africa Confronted with

Climate Change .................................................. 93

Determinants of Small-Scale Farmers' Choice of Adaptive Measures Confronted with

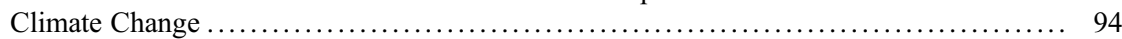

Barriers to Adaptation for Small-Scale Farmers in Africa Confronted with

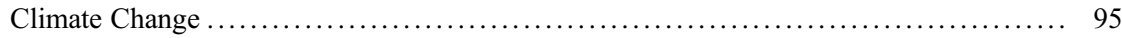

Effectiveness of Small-Scale Farmers' Adaptation Measures in Enhancing Adaptive

Capacity to Climate Change .............................................. 96

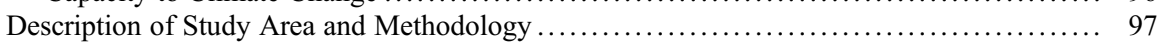

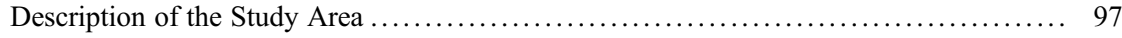

Research Methods ................................................. 97

This chapter was previously published non-open access with exclusive rights reserved by the Publisher. It has been changed retrospectively to open access under a CC BY 4.0 license and the copyright holder is "The Author(s)". For further details, please see the license information at the end of the chapter.

N. P. Awazi $(\bowtie) \cdot$ M. N. Tchamba · L. F. Temgoua · M.-L. Tientcheu-Avana Department of Forestry, Faculty of Agronomy and Agricultural Sciences, University of Dschang, Dschang, Cameroon 


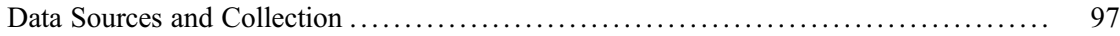

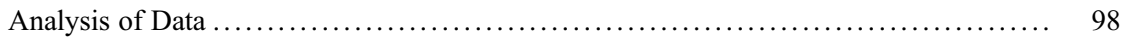

Dependent and Independent Variables .................................... 98

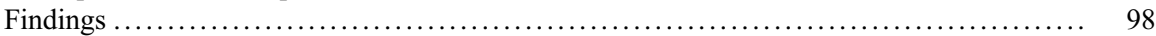

Variations and Changes in Climate Elements ................................ 98

Adaptive Choices of Small-Scale Farmers Confronted with Climate Change Adversities ... 99

Farmer Perceived Factors Influencing Adaptive Capacity to Adverse Climatic Variations

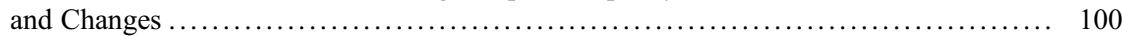

Farmers' Capacity to Adapt to Climate Change ............................... 101

Factors Affecting Small-Scale Farmers' Adaptive Capacity to Climate Change ......... 103

Discussion ........................................................... 106

Variations in Climate Elements ........................................ 106

Adaptive Choices of Small-Scale Farmers Confronted with Climate Change ........... 106

Perceived Factors Affecting Farmers' Adaptive Capacity to Climate Change ........... 107

Non-Cause-Effect and Cause-Effect Relationship Between Small-Scale Farmers'

Adaptive Capacity to Climate Change and Independent/Independent Variables ......... 107

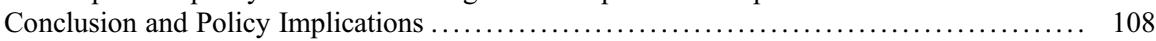

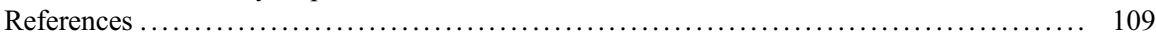

\section{Abstract}

Small-scale farmers' limited adaptive capacity confronted with the adversities of climate change is a major call for concern considering that small-scale farms feed over half of the world's population. In this light, small-scale farmers' adaptive choices and adaptive capacity to climate change were assessed. Data were collected from primary and secondary sources using a mixed research approach. Findings revealed that extreme weather events have been recurrent and small-scale farmers perceived access to land, household income, and the planting of trees/shrubs on farms (agroforestry) as the main factors influencing their capacity to adapt to climate change. Agroforestry and monoculture practices were the main adaptive choices of small-scale farmers confronted with climate change. T-test and chi-square test statistics revealed a strong non-causeeffect relationship ( $p<0.001)$ between small-scale farmers' capacity to adapt to climate change and different socio-economic, institutional, and environmental variables. Parameter estimates of the binomial logistic regression model indicated the existence of a strong direct cause-effect relationship $(p<0.05)$ between small-scale farmers' capacity to adapt to climate change and access to credit, household income, number of farms, access to information, and access to land, indicating that these variables enhance small-scale farmers' capacity to adapt to climate change. It is recommended that policy makers examine the adaptive choices and determinants of farmers' adaptive capacity unearthed in this chapter when formulating policies geared towards enhancing small-scale farmers' capacity to adapt to climate change.

\section{Keywords}

Climate change $\cdot$ Small-scale $\cdot$ Farmers $\cdot$ Adaptive capacity $\cdot$ Africa $\cdot$ Cameroon 


\section{Introduction}

\section{Background of the Study}

The fight against climate change features prominently among the seventeen (17) United Nations Sustainable Development Goals (SDGs) - 2030 Agenda, demonstrating the desire of the global policy making community to tackle climate change, one of the foremost existential threats facing humanity today, head-on (IPCC 2018; Chanana-Nag and Aggarwal 2018; Niles and Salerno 2018). This comes in the wake of unprecedented levels of global warming caused mainly by increasing concentrations of carbon dioxide, methane, nitrous oxides, and other greenhouse gases (GHGs) in the atmosphere (Aggarwal et al. 2015; IPCC 2018). Anthropogenic activities especially excessive fossil fuel combustion, deforestation, and degradation of tropical forests have been singled out as the principal causes of the increasing emissions of greenhouse gases into the atmosphere (Biermann 2007; IPCC 2007; The Royal Society 2010; NAS and RS 2014). With the present climatic variations and changes, humanity has just two choices: adaptation and/or mitigation. With mitigation being a long-term option, adaptation becomes incumbent for different sectors of economic life especially the agricultural sector (Adger et al. 2007; Challinor and Wheeler 2008; Challinor 2009; World Bank 2013; FAO et al. 2018). With the most vulnerable actors in the agricultural sector being small-scale farmers, there is absolute necessity to promote measures that foster adaptation and enhance adaptive capacity to the adversities of climate change.

The FAO (2011) indicated that climate change will seriously threaten the livelihood of small-scale farmers. In 2016, studies demonstrated that small-scale farmers will be adversely affected by changes in climate patterns owing to their limited adaptive capacity (FAO 2016). Small-scale farmers' limited adaptive capacity when confronted with the adversities of climate change is a major call for concern considering that small-scale farmers - who in the majority are found in developing countries - contribute to the nourishment of over half of the world's population (FAO 2016). It is estimated that the developing world has roughly 500 million smallscale farms supporting about two billion people, and these small farms produce about $80 \%$ of the food consumed in Asia and sub-Saharan Africa (IFAD 2012). With the number of small-scale farms across the developing world rising (FAO 2010a, b; IPCC 2014; FAO et al. 2018), it becomes necessary to examine the capacity of smallscale farmers to adapt to climate change adversities and to examine the factors influencing the capacity of small-scale farmers to adapt to the negative effects of climate change.

Cameroon like other developing countries is dominated by food-based agricultural systems. These food-based farming systems owned in the majority by smallscale farmers (who constitute over $90 \%$ of the farming population) have been adversely affected by climate change (Molua 2006, 2008; Tingem et al. 2009; Azibo and Kimengsi 2015; Awazi 2018). Small-scale farmers' capacity to adapt to 
climate change could be enhanced if human, material, logistic, and financial resources are placed at their disposal (Molua 2008; Azibo et al. 2016; Innocent et al. 2016). From this perspective, this chapter sought to assess small-scale farmers' adaptive choices and the determinants of small-scale farmers' capacity to adapt to climate change, in the hope that the findings will go a long way to influence policy and alleviate the plight of small-scale farmers.

\section{Review of Literature}

\section{Perceptions of Climate Change by Small-Scale Farmers in Africa}

Africa's small-scale farmers are increasingly perceptive of climate change, although their perceptions vary on a country-by-country basis as shown by different studies carried out in Africa. In a study carried out by Belaineh et al. (2013) in the Doba District, West Hararghe, Ethiopia, it was found that all male-headed and femaleheaded households perceived the occurrence of climate change. Boissière et al. (2013) on the contrary, in a study carried out in Indonesia - the tropical forests of Papua - found that the local population's perceptions of adverse climatic variations and changes differed significantly across the studied villages. They concluded that these differences in perception of climate change could be due to the different agroecological conditions of the villages. Mtambanengwe et al. (2012) on their part found respondents unanimous that the total quantity of rainfall had declined. The findings of Mtambanengwe et al. (2012) corroborate those of De Wit (2006) and Anderson (2007) who revealed that Southern Africa is becoming increasingly drier, threatening agricultural sustainability, as rainfall distribution within the season fluctuates tremendously.

Maddison (2006), however, found that Zimbabwe's small-scale farmers' perception of climate change varied with respect to the number of years of experience in farming. According to Maddison, small-scale farmers with more than 20 years of experience in farming were more likely to notice significant changes in normal weather patterns compared to their less experienced counterparts. This is corroborated by Mtambanengwe et al. (2012) who also found that 3-4\% of small-scale farmers who claimed not to have noticed any shift in climate in the two communities studied in Zimbabwe were young farmers or farmers mostly involved in off-farm activities.

In a study undertaken in South Africa, Benhin (2006) found that about $72 \%$ of farmers sampled were of the opinion that climate change has been occurring over the years, with delays in the timing of the rain, a drastic drop in the quantity of rain, and higher temperatures. The farmers' perceptions, however, varied slightly across the nine provinces in which the study was carried out. In the semiarid areas of Tanzania, Mary and Majule (2009) found that $63.8 \%$ of farmers sampled in Kamenyanga village and $73.8 \%$ of farmers sampled in Kintinku village perceived an increase in temperature. Farmers reported that the months of September to December were becoming extremely hot and the nights were generally becoming very cold. It was 
also found that most of the farmers sampled perceived a decrease in precipitation and changes in onset of rains as well as an increase in drought frequency in Kamenyanga and Kintinku districts, respectively. Most of the farmers stated that the onset of rainfall has changed because crops were usually planted in the months of October/ November but lately crops are being planted in the months of December/January.

In a study undertaken in eleven (11) African countries, Maddison (2006) found that a large majority of farmers believed that precipitation is declining and temperature is on the rise. Majule et al. (2008) also reported similar findings. Tessema et al. (2013) in a study undertaken in the East Hararghe zone of Ethiopia found that farmers' perceptions differ with respect to changes in precipitation and temperature. A large majority $(91.2 \%)$ of the farmers perceived a rise in temperature, whereas $3.5 \%$ and $5.3 \%$ of the farmers perceived a decrease in temperature and no change, respectively. Most of the farmers $(90.3 \%)$ perceived a drop in the quantity of precipitation; meanwhile $2.6 \%$ and $6.2 \%$ of the farmers perceived an increase in the quantity of precipitation and no change, respectively. Only a small percentage $(0.9 \%)$ of the farmers indicated that precipitation is variable rather than agreeing either on an increase or decrease in the quantity of rainfall.

In the same line of thought, studies undertaken across different parts of Africa have shown that small-scale farmers perceive climate change through variations in climate elements. Studies undertaken by Ishaya and Abaje (2008) in Kaduna state, Nigeria; Gbetibouo (2009) in the Limpopo Basin of South Africa; Mertz et al. (2009) in the Rural Sahel; Deressa et al. (2011) in the Nile Basin of Ethiopia; Nyanga et al. (2011) in Zambia; Nzeadibe et al. (2012) in the Niger Delta Region of Nigeria; Tambo and Abdoulaye (2012) in Nigeria; Yaro (2013) in Ghana; Juana et al. (2013) in sub-Saharan Africa (synthesis of empirical studies); Temesgen et al. (2014) in Ethiopia; Mulenga and Wineman (2014) in Zambia; and Aggarwal et al. (2015) in the Kullu District of the western Himalayan region all found that small-scale farmers were increasingly perceptive of climate change. Based on the findings of all these studies, a conclusion could be drawn to the effect that small-scale farmers' perceptions of climate change are quasi-unanimous across Africa.

\section{Adverse Effects of Climate Change on Africa's Small-Scale Farmers}

Africa's small-scale farmers are increasingly being affected by climate change. Scholarship indicates that climate change has mainly adverse effects on Africa's small-scale farming communities. In a study carried out in Kenya, Herrero et al. (2010) found that climate change adversely affected small-scale farmers through recurrent droughts. Mary and Majule (2009) carried out a study in Tanzania, revealing that the recurrence of extreme climate events (changing rainfall and temperature patterns) led to increased risk of crop failure owing to the washing away of seeds and crops, stunted growth, poor seed germination, and withering of crops. It was equally found that, in the case of livestock, variations in rainfall patterns (decreased rainfall-drought and increased rainfall-floods) led to a decrease in pasture and an increase in parasites and diseases. Similar findings have been 
reported by other studies carried out in Africa. Mortimore and Adams (2001), for example, found that the timing of the onset of the first rains and other intra-seasonal factors such as the effectiveness of the rains in each precipitation, and the distribution and length of the period of rain during the growing season, seriously affect cropplanting regimes as well as the effectiveness and success of farming. According to the IPCC (2007), changes in rainfall patterns and the quantity of rainfall affect soil moisture and the rate soil erosion, both prerequisites for crop growth and crop yields. All these negatively affect small-scale farmers.

In a study assessing the economic impact of climate change on agriculture in Cameroon, Molua and Lambi (2006) found that as temperature increases, and precipitation decreases, net revenue dropped across all the surveyed farms. The study equally revealed that an increase in temperature by $2.5{ }^{\circ} \mathrm{C}$ will lead to a drop in net revenues from agriculture in Cameroon by $\$ 0.5$ billion. A $5{ }^{\circ} \mathrm{C}$ increase in temperature on its part will lead to a drop in net revenues by $\$ 1.7$ billion. A $7 \%$ decrease in precipitation will lead to a drop in net revenues by $\$ 1.96$ billion, and a $14 \%$ decrease in precipitation will lead to a drop in net revenues from crops by $\$ 3.8$ billion. The study, however, found that increases in precipitation will lead to an increase in net revenues. Based on these findings, small-scale farmers in Cameroon will be adversely affected by climate change through a fall in farm revenue.

On their part, Tabi et al. (2012), in a study carried out in the Volta region of Ghana, found that climate change adversely affects rice farmers. These adverse effects were death of animals, loss of farming capital, heat stress, increase in social vices, shortage of water, slow development, and increased poverty and food insecurity. From these findings and those of other studies aforementioned, it could be said that climate change has mainly adverse or negative effects on small-scale farmers in Africa.

\section{Drivers of Small-Scale Farmers' Vulnerability to Climate Change in Africa}

In the face of climate change adversities, small-scale farmers in Africa are the most vulnerable actors involved in the agricultural sector (Rurinda 2014). Small-scale farmers' vulnerability to climate change adversities could be attributed to several factors. In a study carried out to examine the vulnerability of small-scale farming systems of Zimbabwe to climate change, Rurinda (2014) and Rurinda et al. (2014) found that the main causes or sources of vulnerability of small-scale farmers to climate change were lack of knowledge, lack of draught power, increased rainfall variability, lack of seed, lack of fertilizer, and declining soil fertility. Following Rurinda's findings, the single most important source or cause of small-scale farmers' vulnerability to climate change was increasing variability in rainfall.

In a study assessing rice farming in the Volta region of Ghana, Tabi et al. (2012) showed that the main sources or causes of rice farmers' vulnerability to climate change were low price of rice in the local market, difficult land tenure system, limited or no access to credit facilities, few farmers engaged in off-farm activities, poor soils, and lack of insurance in times of crop failure. 
The CDCCP (2009), in a study undertaken in the Chiredzi district of Zimbabwe, found that the main causes of small-scale farmers' vulnerability to climate change were as follows: poor farming practices, high frequency of drought, inherent dryness, limited use of climate early warning systems, over-dependence on monocropping especially maize, high incidence of poverty, population pressure, skewed ownership and access to drylands' livelihood assets such as livestock and wildlife, lack of drought preparedness plans, limited alternative livelihood options outside agriculture, and low access to technology (irrigation, seed), markets, institutions, and infrastructure (poor roads, bridges, modern energy, dams and water conveyance).

These findings therefore demonstrate that small-scale farmers in Africa are highly vulnerable to the adverse effects of climate change.

\section{Adaptation Options Implemented by Small-Scale Farmers in Africa Confronted with Climate Change}

In Africa, small-scale farmers have adopted different adaptive options in order to improve their adaptive capacity confronted with climate change. Tabi et al. (2012) while assessing rice farming in the Volta region of Ghana found that rain-fed lowland rice farmers practiced different adaptive choices among which were the application of fertilizers, water management control practices, alternation of planting dates, herbicide use, and the use of high-yielding and disease-resistant varieties. On their part, Kuwornu et al. (2013) in a study carried out in northern Ghana found that smallscale farmers adopted both indigenous and introduced (modern) adaptive options to improve their adaptive capacity to climate change.

Molua and Lambi (2006), in a study undertaken in Cameroon, found that the main indigenous adaptation strategies implemented by small-scale farmers in the face of climate change were changing timing of farming operations, increasing planting space, undertaking traditional and religious ceremonies, change of crops, varying area cultivated, and cultivation of short season local varieties. The FAO (2006) found that the major indigenous adaptation strategies practiced by small-scale farmers were reducing food intake, change of crops, reducing personal expenditures, mortgaging land, homestead gardening, disposing of productive harvests, and re-sowing or replanting.

Different authors have carried out studies across Africa with varying findings as far as indigenous adaptive choices implemented by small-scale farmers confronted with climate change adversities are concerned. For example, studies carried out by Hassan and Nhemachena (2008), the FAO (2008, 2009b), Gbetibouo (2009), and Deressa et al. (2010) showed that diversification of crops is a major indigenous strategy practiced by small-scale farmers confronted with climate change adversities. Studies carried out by Easterling et al. (2007), Boko et al. (2007), Gbetibouo (2009), the FAO (2009a, 2010c), and Deressa et al. (2010) showed that the integration of livestock to crop production is a key indigenous strategy practiced by small-scale farmers confronted with climate change. Studies undertaken by Molua and Lambi (2006), Easterling et al. (2007), Boko et al. (2007), Hassan and 
Nhemachena (2008), Gbetibouo (2009), and the FAO (2009b) revealed that changing the timing of farm operations is one of the most important indigenous strategies adopted by small-scale farmers in the face of climate change. The FAO (2006, 2009b), Molua and Lambi (2006), and Gbetibouo (2009) found that changing of crops was a major adaptation strategy used by small-scale farmers to adapt to climate change. The FAO (2006) and Altieri and Koohafkan (2008) found that home gardening was a major indigenous strategy practiced by smallscale farmers confronted with climate change adversities.

The FAO (2010a), Thorlakson (2011), Rao et al. (2011), Mbow et al. (2013), Bishaw et al. (2013), Mbow et al. (2014), Kabir et al. (2015) and Awazi and Tchamba (2019), found that agroforestry practices like scattered trees on croplands, improved fallows, home gardens, and cocoa, coffee, and banana agroforests were sustainable and climate-smart adaptive choices practiced by small-scale farmers across Africa in the face of climate change.

From the foregoing, small-scale farmers are adopting both indigenous and introduced adaptive measures to adapt to the adverse effects of climate change across Africa. However, very little has been done to assess the adaptive capacity of smallscale farmers in the face of climate change.

\section{Determinants of Small-Scale Farmers' Choice of Adaptive Measures Confronted with Climate Change}

Small-scale farmers' choice of adaptive measures confronted with climate change was influenced by several factors. Tabi et al. (2012), in a study carried out to assess the different adaptive choices of small-scale rice farmers in Ghana, found that the main variables influencing the different adaptive options of small-scale farmers were distance to farm and market, labor, advice from extension agents, gender, length of stay in rice farm, age, farm size, number of farms, credits, household size, and education. Deressa et al. (2008) and Atinkut and Mebrat (2016) on their part found that different infrastructural and institutional factors as well as household and farm characteristics influenced the adaptive choices of small-scale farmers confronted with adverse climatic changes. Through marginal analysis, Deressa et al. (2008), in a study carried out in the Nile Basin of Ethiopia, found that institutional factors (availability of information), social capital, household variables, agro-ecological features, and wealth attributes influenced small-scale farmers' adaptive choices confronted with climate change in the Nile Basin of Ethiopia.

Studies carried out by Maddison 2006 and Nhemachena and Hassan (2007) showed that the most common household attributes influencing small-scale farmers' adaptive capacity to climate change adversities were wealth, marital status, farming experience, age, education, and gender of the head of household; common farm attributes influencing small-scale farmers' adaptive choices to climate change included fertility, slope, and farm size; common institutional factors affecting adaptive choices of small-scale farmers to adverse climatic changes included credit accessibility and access to extension services; and the common infrastructural factor 
influencing small-scale farmers' adaptive capacity to climate change was distance to input and output markets. Across Africa, different studies have been carried out assessing the impact of climate change and factors affecting small-scale farmers' adaptive choices in crop, livestock, and mixed crop-livestock production systems confronted with climate change adversities (Maddison 2006; Hassan and Nhemachena 2008; Kurukulasuriya and Mendelsohn 2007). However, Zivanomoyo and Mukarati (2012) assessed the factors affecting small-scale farmers' choice of crop varieties confronted with climate change adversities. The study sought to examine how farmers' choice of different crop varieties contributed to improve their adaptive capacity to climate change. Findings revealed that the use of more disease-resistant and hybrid varieties contributed in a major way towards enhancing the adaptive capacity of small-scale farmers to climate change.

From the foregoing, the factors influencing the adaptive choices of small-scale farmers confronted with climate change adversities could be broadly classified into institutional, environmental, and socio-economic factors. Although the factors influencing the adaptive choices of small-scale farmers confronted with climate change have been examined by different studies across Africa, little has been done to assess the small-scale farmers' adaptive capacity to climate change.

\section{Barriers to Adaptation for Small-Scale Farmers in Africa Confronted with Climate Change}

In Africa, small-scale farmers have increasingly faced difficulties adapting to the adverse effects of climate change because of different factors. Tabi et al. (2012), in a study carried out on small-scale rice farmers in the Upper Volta region of Ghana, found that the main barriers to small-scale farmers' adoption of different adaptive options confronted with climate change were lack of equipment for quick and appropriate land preparation, lack of farm inputs, inadequate or no irrigation facilities, inadequate or no weather forecast, and limited access to credits. Deressa et al. (2008) in a study carried out in the Nile Basin of Ethiopia found that five major constraints affected small-scale farmers' adaptation choices to climate change. These barriers were shortage of land, shortage of labor, poor potential for irrigation, lack of money, and lack of information. The study however found that most of the constraints to small-scale farmers' adaptation to climate change could be largely attributed to poverty. Deressa et al. $(2009,2011)$, in studies undertaken in the Nile Basin of Ethiopia, equally demonstrated that poverty is a major barrier to small-scale farmers' adaptation to climate change, because lack of money makes it difficult for small-scale farmers to get the required resources and technologies that ease adaptation to climate change.

In a study carried out in the coastal regions of Bangladesh, Kabir et al. (2015) found that the main constraints to climate change adaptation for small-scale farmers were lack of information, lack of credit, unpredicted weather, shortage of land, shortage of farm inputs, and lack of water. Tessema et al. (2013), in a study carried out in the Eastern Hararghe Zone of Ethiopia, discovered that the major constraints 
to climate change adaptation for small-scale farmers were shortage of land, lack of seed, shortage of labor, limited market access, lack of money, lack of water, lack of fertilizer, lack of oxen, insecure land tenure, and lack of information. In different parts of Ethiopia, studies have shown that small-scale farmers face several difficulties in their drive to adapt to climate change (Maddison 2007; Deressa et al. 2009, 2011; Bryan et al. 2009; Mersha and Laerhoven 2016).

The aforementioned studies indicate that, small-scale farmers' inability to adapt to climate change is largely due to different barriers. However, limited work has been done to examine the adaptive capacity of small-scale farmers confronted with climate change and the barriers to small-scale farmers' capacity to adapt to climate change.

\section{Effectiveness of Small-Scale Farmers' Adaptation Measures in Enhancing Adaptive Capacity to Climate Change}

In Africa, the effectiveness of small-scale farmers' adaptive choices confronted with climate change varies tremendously. Kuwornu et al. (2013) carried out a study to assess the adaptive options of small-scale farmers confronted with climate change adversities and the effectiveness of these adaptive options. They found that among the different indigenous strategies used by small-scale farmers to adapt to the adversities of climate change, the strategies comprising of timing of rainfall and early or late planting were ranked by small-scale farmers in northern Ghana as the most effective strategy used in adapting to adverse climate change while soil-related strategies were ranked as the least effective indigenous strategy used by small-scale farmers. Kuwornu et al. (2013) equally found that among the introduced adaptation strategies (adaptation strategies introduced by research), soil and plant health strategies were ranked by small-scale farmers as the most effective introduced strategy enhancing adaptation to climate change, while non-adoption of any of the introduced strategies was quasi-unanimously ranked by small-scale farmers as the least effective way of adapting to the adverse effects of changing climatic conditions. Hadgu et al. (2015) in a study undertaken in the Tigray region of northern Ethiopia found that changing of crop variety/type was ranked by small-scale farmers as the most effective adaptation strategy to climate change while the "No" adaptation strategy was the least effective way to adapt to the adversities of changing climatic conditions.

The review of previous literature enabled the authors of this chapter to understand what had been done on the African continent in general and Cameroon in particular as far as small-scale farmers' adaptation and adaptive capacity to climate change were concerned. It equally afforded the authors the opportunity to identify some independent variables used in the chapter. However, it was found that while many authors had undertaken studies which revealed that small-scale farmers adopt different adaptive choices in the face of climate change, little had been done to examine small-scale farmers' adaptive capacity to climate change. This work was therefore initiated in a bid to fill the knowledge gap. 


\section{Description of Study Area and Methodology}

\section{Description of the Study Area}

The study was carried out in the north-west region of Cameroon. The north-west region of Cameroon lies between longitude $9^{\circ} 30^{\prime} \mathrm{E}$ to $11^{\circ} 15^{\prime} \mathrm{E}$ and latitude $5^{\circ} 4^{\prime} \mathrm{N}$ to $7^{\circ} 15^{\prime} \mathrm{N}$. The north-west region of Cameroon covers a total surface area of about $17,812 \mathrm{~km}^{2}$ and hosts a population of over $1,840,500$ inhabitants, which gives a population density of roughly 103 inhabitants $/ \mathrm{km}^{2}$ making it one of the most densely populated regions in Cameroon. The climate is tropical, and the vegetation is mostly made up of savannah grassland, interspersed with some forest patches. The topography is rolling and characterized by mountains like Mount Oku and plains like the Ndop and Mbaw plains.

\section{Research Methods}

\section{Study Site Selection and Sampling Methods}

The multiphase sampling procedure was employed. At the first phase, the area of study (the north-west region of Cameroon) was selected purposively owing to the presence of mainly small-scale farmers and the high levels of vulnerability of these small-scale farmers to climate change. At the second phase, ten villages were randomly selected from the different sub-districts found in the north-west region of Cameroon, taking into cognizance the agro-ecological, socio-economic, and environmental attributes of the different sub-districts. This was done with the help of agricultural extension agents working in the area. The third phase involved focus group discussions with small-scale farmers and key informant interviews with resource persons. This was done in order to get general information on the adaptive capacity of small-scale farmers and to triangulate this information with that gotten from small-scale farmers during household surveys. In the fourth and last phase, household surveys were conducted in the ten villages using the simple random sampling approach. With the use of semi-structured questionnaires, a total of 350 small-scale farmer household heads were sampled in the ten villages.

\section{Data Sources and Collection}

Both secondary and primary data were collected. Secondary data were collected primarily through the review of relevant literature from previous scientific studies as well as climate data from meteorological stations in the study area. Primary data were collected through a survey of 350 small-scale farmer household heads, complemented with focus group discussions, key informant interviews with resource persons, and overt observations.

Through the use of five-point Likert scale-style questions during household surveys, farmers were asked to rank their adaptive capacity to climate change 
based on their livelihood capital assets. These livelihood capital assets were natural, human, social, financial, and physical. These different capital assets constituted the independent variables of the study. It was on the basis of these capital assets that farmers ranked their adaptive capacity to climate change to be high, low, or no adaptive capacity.

\section{Analysis of Data}

Primary data collected on the field was coded and imputed into Microsoft Excel 2007 and SPSS 20.0 statistical packages for descriptive and inferential statistical analysis. Descriptive statistics computed were charts and percentage indices, while inferential statistics computed were t-test statistic, chi-square test, and logistic regression.

The independent samples t-test and chi-square $\left(\boldsymbol{X}^{2}\right)$ test statistics were used to identify the non-cause-effect relationship between small-scale farmers' capacity to adapt to climate change and independent variables.

The binary logistic (BNL) regression model on its part was used to examine the cause-effect relationship between small-scale farmers' capacity to adapt to climate change and independent variables. The binary logistic regression model predicts the $\log$ ODDS of having made one decision or the other. This model permits the analysis of decisions across two categories (Di Falcao et al. 2011; Awazi and Tchamba 2018).

\section{Dependent and Independent Variables}

Both dependent and independent variables were used. The dependent variable was adaptive capacity (binary, i.e., adaptive/not adaptive), while the independent or independent variables (different capital assets) were age of household head, household size, number of farms, income of household, educational level, gender of household head, practice of agroforestry, vulnerability to climate change, information accessibility, credit accessibility, land accessibility, and access to extension services. Because the dependent and independent variables were mainly qualitative in nature, the statistical analyses were done using non-parametric tests and the discrete regression model (binomial logistic regression).

\section{Findings}

\section{Variations and Changes in Climate Elements}

The analysis of over five decades of climate data revealed significant variations in climate parameters (Figs. 1, 2, and 3). In the past 58 years (1961-2018), temperature fluctuations were high, and most of the years experienced above mean temperature, implying that temperature is becoming higher than usual. Meanwhile the total 


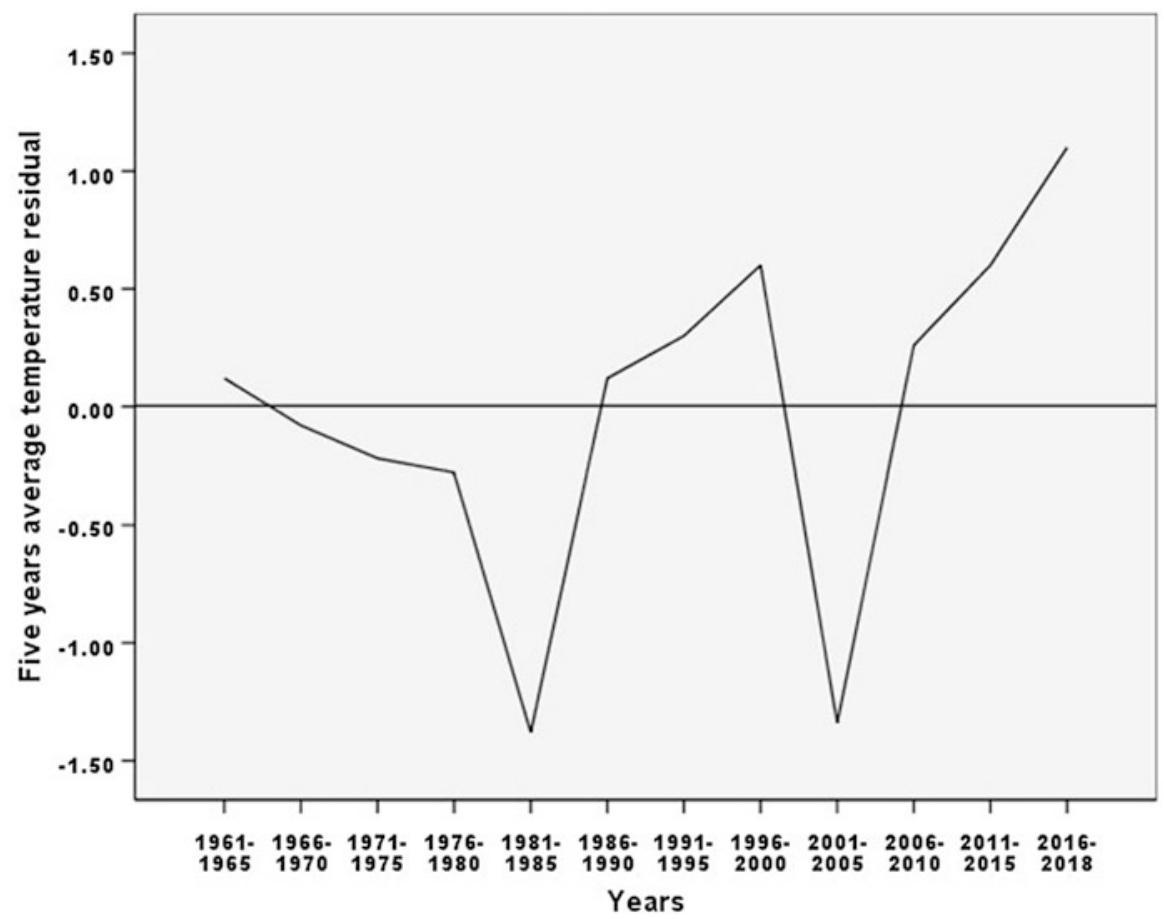

Fig. 1 Temperature variation 1961-2018

quantity of rainfall and number of rainy days equally experienced marked levels of fluctuation, with most of the years experiencing a decrease in amount of rainfall and fewer rainy days. This indicates that the amount of rainfall has been scanty while the number of rainy days has been erratic. These high levels of fluctuation in climate parameters within the past 58 years could therefore be seen as an indicator of climatic variations and changes.

In the face of climatic variations and changes, the relationship between the different climate parameters varied. Scatter plots indicated the existence of an insignificant negative correlation between rainfall and temperature, and rainy days and temperature. Meanwhile a relatively strong positive correlation was found to exist between rainfall and rainy days.

\section{Adaptive Choices of Small-Scale Farmers Confronted with Climate Change Adversities}

An analysis of small-scale farmers' adaptive choices confronted with climate change showed that a majority of the small-scale farmers (74\%) were practicing agroforestry on their farm plots (Table 1). Among the agroforestry practices most patronized by 


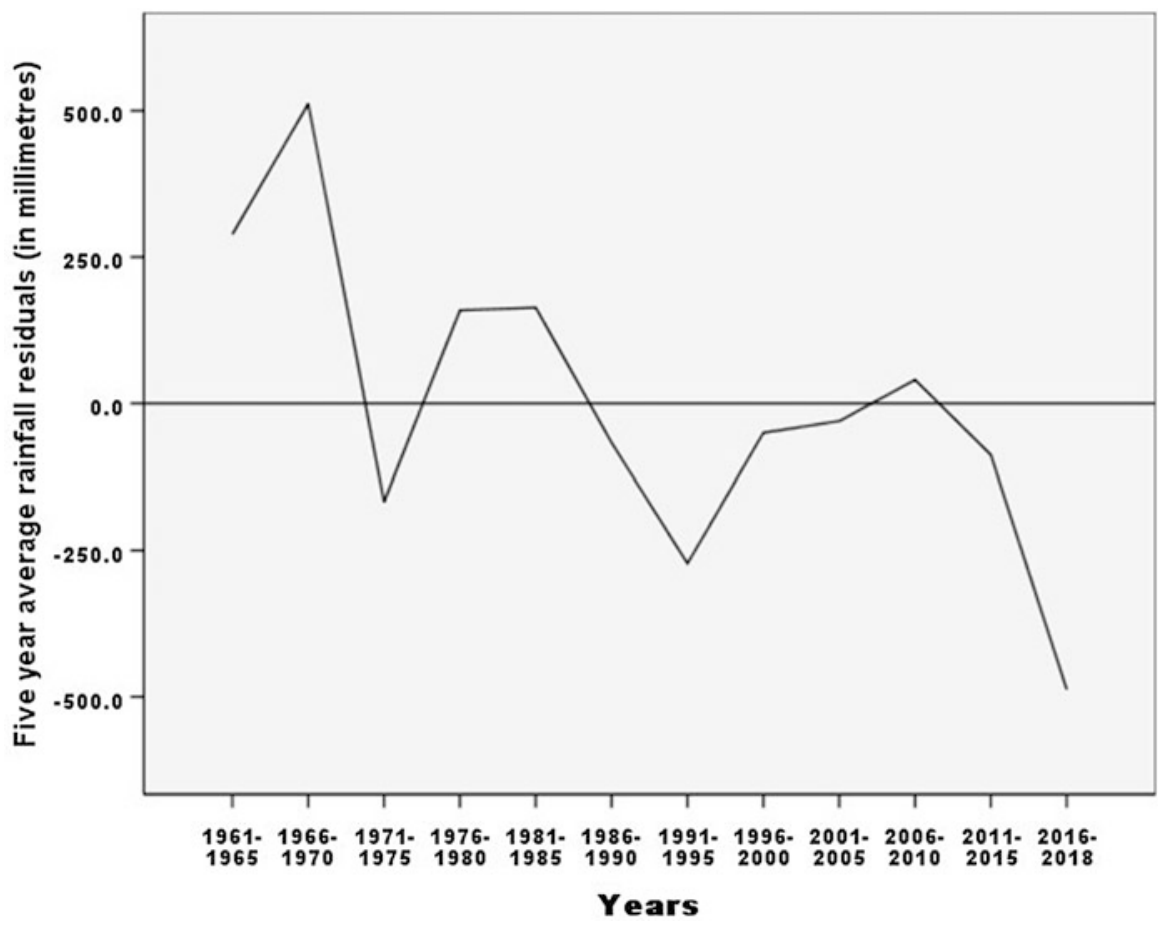

Fig. 2 Variation in rainfall 1961-2018

small-scale farmers confronted with adverse climatic variations and changes were home gardens with livestock (13\%), home garden (11\%), trees on croplands $(11 \%)$, live fences/hedges (11\%), and coffee-based agroforestry (9\%) (Table 1).

Equally, some small-scale farmers confronted with adverse climatic variations and changes practiced monoculture (Table 1). The most common monoculture and mono-livestock practices of small-scale farmers confronted with adverse climatic variations and changes were market gardening monoculture $(8 \%)$, cash crop monoculture $(7 \%)$, and food crops monoculture $(9 \%)$.

\section{Farmer Perceived Factors Influencing Adaptive Capacity to Adverse Climatic Variations and Changes}

Assessing small-scale farmers' adaptive capacity to adverse climatic variations and changes (Fig. 4), it was found that all the small-scale farmers perceived land accessibility (100\%) and income of household (100\%) as being the main factors influencing adaptive capacity to climate change.

Agroforestry (82\%), accessibility to markets (77\%), credit accessibility (72\%), information accessibility (65\%), and access to extension services (55\%) were 


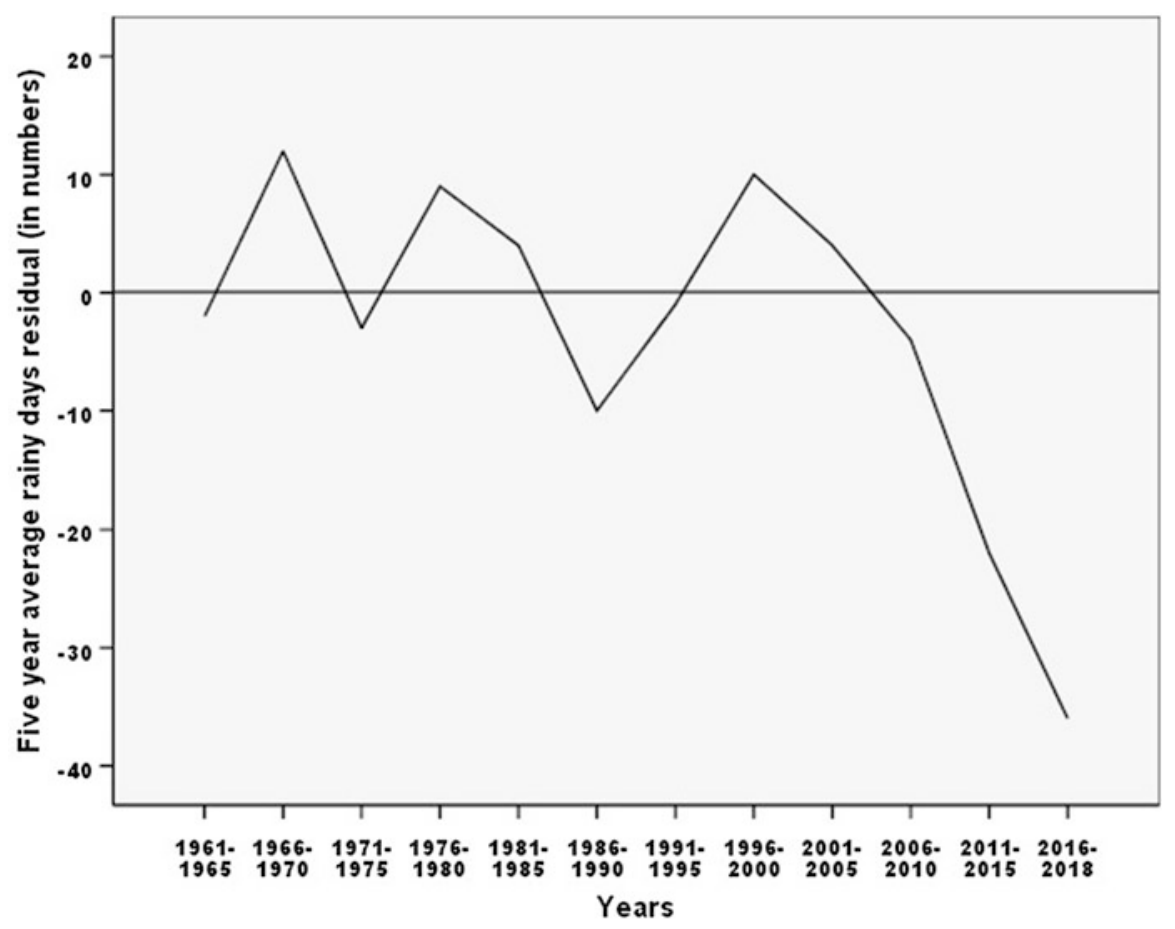

Fig. 3 Variation in rainy days 1961-2018

equally perceived by small-scale farmers as being among the key factors affecting adaptive capacity to climate change. Other least perceived factors influencing adaptive capacity to climate change were irrigation (31\%) and others (14\%) like road network and topography. However, it is worth mentioning that the main factors influencing small-scale farmers' adaptive capacity to climate change were land accessibility, income of household, agroforestry, accessibility to markets, credit accessibility, and information accessibility (Fig. 4).

\section{Farmers' Capacity to Adapt to Climate Change}

Concerning the adaptive capacity of small-scale farmers to climate change (Fig. 5), most small-scale farmers perceived that on the basis of their livelihood capital assets, they were not adaptive (58\%).

Meanwhile $14 \%, 20 \%$, and $4 \%$ of small-scale farmers perceived that, on the basis of their livelihood capital assets, they were adaptive, less adaptive, and much less adaptive, respectively, to climate change. Only $4 \%$ of small-scale farmers perceived that, on the basis of their livelihood capital assets, they were highly adaptive to climate change. From these perceptions, it was noticed that most small-scale farmers had a limited capacity to adapt to climate change (Fig. 5). 
Table 1 Small-scale farmers' adaptive choices confronted with the adverse effects of climate change

\begin{tabular}{l|l|l}
\hline $\begin{array}{l}\text { Farmers' adaptive choice confronted with climate change } \\
\text { adversity }\end{array}$ & $\begin{array}{l}\text { Frequency } \\
(\mathrm{n})\end{array}$ & $\begin{array}{l}\text { Percent } \\
(\%)\end{array}$ \\
\hline 1. Agroforestry practices & 35 & 13 \\
\hline a. Home garden with livestock & 30 & 11 \\
\hline b. Home garden & 30 & 11 \\
\hline c. Trees on croplands & 30 & 11 \\
\hline d. Live fences/hedges & 20 & 7 \\
\hline e. Taungya & 15 & 6 \\
\hline f. Trees on grazing lands & 10 & 4 \\
\hline g. Improved fallows & 25 & 9 \\
\hline h. Coffee-based agroforestry & 5 & 2 \\
\hline i. Others (entomoforestry, aquaforestry) & $\mathbf{2 0 0}$ & $\mathbf{7 4}$ \\
\hline Total & & \\
\hline 2. Monoculture and mono-livestock practices & 20 & 8 \\
\hline a. Market gardening crops only & 20 & 7 \\
\hline b. Cash crops only & 25 & 9 \\
\hline c. Food crops only & 5 & 2 \\
\hline d. Livestock only & $\mathbf{7 0}$ & $\mathbf{2 6}$ \\
\hline Total & $\mathbf{2 7 0}$ & $\mathbf{1 0 0}$ \\
\hline N & &
\end{tabular}

Source: Adapted from Awazi et al. 2020

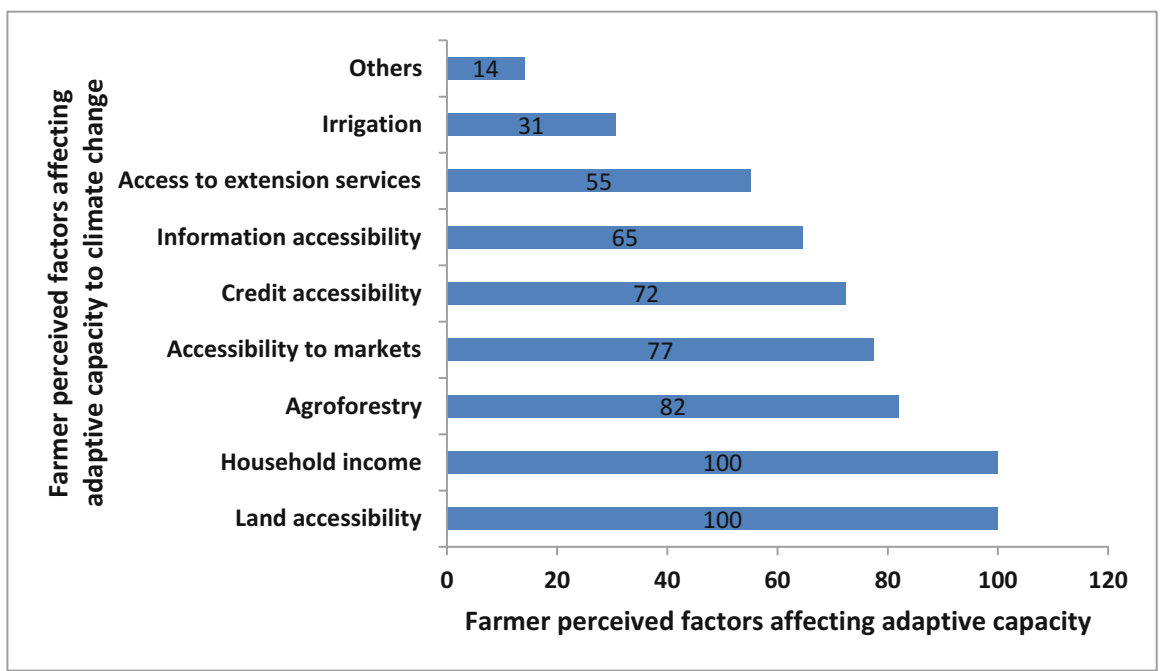

Fig. 4 Factors influencing adaptive capacity to climate change perceived by small-scale farmers 


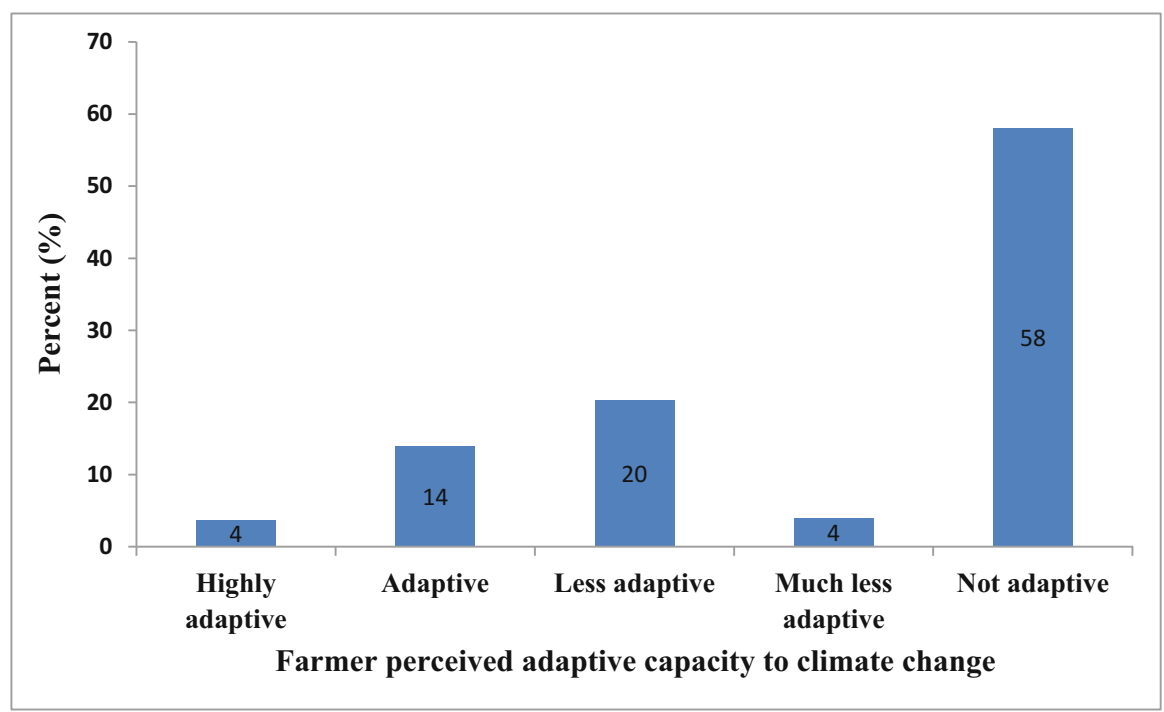

Fig. 5 Adaptive capacity to climate change perceived by small-scale farmers

Table 2 Non-cause-effect relationship between small-scale farmers' adaptive capacity to climate change and four continuous independent variables

\begin{tabular}{l|l|l|l|r}
\hline & \multicolumn{4}{l}{ T-test for equality of means } \\
\hline Independent variable & $\mathrm{t}$ & $\mathrm{df}$ & $\mathrm{p}$-level & Mean diff. \\
\hline Number of farms & -10.776 & 170.493 & $0.000^{* * *}$ & -2.940 \\
\hline Household size & -7.552 & 195.262 & $0.000^{* * *}$ & -1.590 \\
\hline Age of household head & -8.224 & 209.441 & $0.000^{* * *}$ & -5.192 \\
\hline $\begin{array}{l}\text { Income of household } \\
\text { (in FCFA) }\end{array}$ & -9.062 & 179.442 & $0.000^{* * *}$ & -179415.9 \\
\hline
\end{tabular}

${ }^{* * *}$ Significant at $1 \%$ probability level

\section{Factors Affecting Small-Scale Farmers' Adaptive Capacity to Climate Change}

\section{Non-Cause-Effect Relationship Between Small-Scale Farmers' Adaptive Capacity and Continuous Independent Variables}

T-test statistics showed that there was a significant non-cause-effect relationship between small-scale farmers' adaptive capacity and four continuous independent variables (Table 2).

The continuous independent variables (number of farms $(\mathrm{t}=10.776, p<0.001)$, size of household $(\mathrm{t}=7.552, p<0.001)$, age of household head $(\mathrm{t}=8.224$, $p<0.001)$, and income of household $(\mathrm{t}=9.062, p<0.001))$ all had a significant non-cause-effect relationship with small-scale farmers' adaptive capacity to climate change. This demonstrates that the number of farms owned, size of household, age of 
household head, and income of household play an important role in influencing the adaptive capacity of small-scale farmers confronted with climate change.

\section{Non-Cause-Effect Relationship Between Small-Scale Farmers' Adaptive Capacity and Qualitative Independent Variables}

Chi-square test statistics showed that there was a significant non-cause-effect relationship between small-scale farmers' adaptive capacity to climate change and seven (07) qualitative independent variables (Table 3).

The qualitative independent variables (level of education of household head $\left(X^{2}=123.10, p<0.001\right)$, gender of household head $\left(X^{2}=24.95, p<0.001\right)$, practice of agroforestry $\left(X^{2}=64.50, p<0.001\right)$, information accessibility $\left(X^{2}=44.70, p<0.001\right)$, credit accessibility $\left(X^{2}=90.88, p<0.001\right)$, land accessibility $\left(X^{2}=52.50, p<0.001\right)$, and access to agricultural extension services $\left.\left(X^{2}=21.54, p<0.001\right)\right)$ all had a significant non-cause-effect relationship with small-scale farmers' adaptive capacity to climate change. This confirms that the level of education of household head, gender of household head, practice of agroforestry, access to information, access to credit, access to land, and access to

Table 3 Non-cause-effect relationship between small-scale farmers' adaptive capacity and qualitative independent variables

\begin{tabular}{|c|c|c|c|c|c|c|c|c|}
\hline \multirow{2}{*}{$\begin{array}{l}\text { Qualitative } \\
\text { independent } \\
\text { variable }\end{array}$} & \multirow[b]{2}{*}{ Description } & \multicolumn{2}{|c|}{$\begin{array}{l}\text { Frequency } \\
\text { (n) }\end{array}$} & \multicolumn{2}{|c|}{$\begin{array}{l}\text { Percentage } \\
(\%)\end{array}$} & \multirow[b]{2}{*}{$\begin{array}{l}\text { Chi- } \\
\text { square }\end{array}$} & \multirow[b]{2}{*}{ L.R. } & \multirow[b]{2}{*}{ p-level } \\
\hline & & A. & $\begin{array}{l}\text { N. } \\
\text { A. }\end{array}$ & A. & N.A. & & & \\
\hline \multirow{5}{*}{$\begin{array}{l}\text { Educational } \\
\text { level of } \\
\text { household } \\
\text { head }\end{array}$} & $\begin{array}{l}\text { No formal } \\
\text { edu. }\end{array}$ & 11 & 21 & 3.14 & 6 & \multirow[t]{5}{*}{123.10} & \multirow[t]{5}{*}{141.69} & \multirow[t]{5}{*}{$0.000^{* * *}$} \\
\hline & Primary & 62 & 180 & 17.71 & 51.43 & & & \\
\hline & Secondary & 10 & 0 & 2.86 & 0 & & & \\
\hline & $\begin{array}{l}\text { High } \\
\text { school }\end{array}$ & 34 & 1 & 9.71 & 2.86 & & & \\
\hline & Tertiary & 30 & 1 & 8.57 & 2.86 & & & \\
\hline \multirow{2}{*}{$\begin{array}{l}\text { Gender of } \\
\text { household } \\
\text { head }\end{array}$} & Male & 104 & 89 & 29.71 & 25.43 & \multirow[t]{2}{*}{24.95} & \multirow[t]{2}{*}{25.47} & \multirow[t]{2}{*}{$0.000^{* * *}$} \\
\hline & Female & 43 & 114 & 12.28 & 32.57 & & & \\
\hline \multirow{2}{*}{$\begin{array}{l}\text { Practice } \\
\text { agroforestry }\end{array}$} & Yes & 147 & 132 & 42 & 37.71 & \multirow[t]{2}{*}{64.50} & \multirow[t]{2}{*}{90.23} & \multirow[t]{2}{*}{$0.000^{* * *}$} \\
\hline & No & 0 & 71 & 0 & 20.28 & & & \\
\hline \multirow{2}{*}{$\begin{array}{l}\text { Information } \\
\text { accessibility }\end{array}$} & Yes & 42 & 7 & 12 & 2 & \multirow[t]{2}{*}{44.70} & \multirow[t]{2}{*}{46.69} & \multirow[t]{2}{*}{$0.000^{* * *}$} \\
\hline & No & 105 & 196 & 30 & 56 & & & \\
\hline \multirow{2}{*}{$\begin{array}{l}\text { Credit } \\
\text { accessibility }\end{array}$} & Yes & 64 & 5 & 18.28 & 1.43 & \multirow[t]{2}{*}{90.88} & \multirow[t]{2}{*}{99.25} & \multirow[t]{2}{*}{$0.000^{* * *}$} \\
\hline & No & 83 & 198 & 23.71 & 56.57 & & & \\
\hline \multirow{2}{*}{$\begin{array}{l}\text { Land } \\
\text { accessibility }\end{array}$} & Yes & 51 & 10 & 14.57 & 2.86 & \multirow[t]{2}{*}{52.50} & \multirow[t]{2}{*}{54.33} & \multirow[t]{2}{*}{$0.000^{* * *}$} \\
\hline & No & 96 & 193 & 27.43 & 55.14 & & & \\
\hline \multirow{2}{*}{$\begin{array}{l}\text { Access to } \\
\text { extension }\end{array}$} & Yes & 45 & 22 & 12.86 & 6.29 & \multirow[t]{2}{*}{21.54} & \multirow[t]{2}{*}{21.41} & \multirow[t]{2}{*}{$0.000^{* * *}$} \\
\hline & No & 102 & 181 & 29.14 & 51.71 & & & \\
\hline
\end{tabular}

*** Significant at $1 \%$ probability level; A. = adaptive; N.A. = not adaptive; L.R. = likelihood ratio 
agricultural extension services influence small-scale farmers' adaptive capacity to climate change.

\section{Binary Logistic Regression Model Predicting Small-Scale Farmers' Adaptive Capacity to Climatic Change from Independent Variables}

The parameter estimates of the binary logistic regression model revealed that five main independent variables played a statistically significant role in influencing small-scale farmers' adaptive capacity to climate changes (Table 4).

From the parameter estimates of the binary logistic regression model, the number of farms $(\beta=0.271, p<0.05)$, information accessibility $(\beta=0.937, p<0.1)$, credit accessibility $(\beta=1.596, p<0.05)$, income of household $(\beta=1.821, p<0.01)$, and land accessibility $(\beta=1.029, p<0.05)$ all had a significant direct cause-effect relationship with small-scale farmers' adaptive capacity to climate change. This implies that as the number of farms, information accessibility, credit accessibility, household income, and land accessibility increase, small-scale farmers' adaptive capacity to climate change also increases.

It is important to note that the parameter estimates of this model were valid looking at the likelihood ratio $X^{2}$, the number of cases correctly classified, and the Nagelkerke $\mathrm{R}^{2}$. The likelihood ratio $X^{2}(5, n=350=145.835, p<0.01)$ indicated that the model was statistically significant and had a strong explanatory power. The model correctly classified up to $80 \%$ of the factors influencing small-scale farmers' adaptive capacity to climate change. Looking at the Nagelkerke $\mathrm{R}^{2}$ (Pseudo $\mathrm{R}^{2}$ ) of the model which stood at 0.648 , it revealed that up to $64.8 \%$ of the changes in smallscale farmers' adaptive capacity to climate change could be explained by changes in the continuous and qualitative independent variables of the model. Hence, from the values of the likelihood ratio $X^{2}$, the number of cases correctly classified, and the Nagelkerke $\mathrm{R}^{2}$, it could be said that the predictions of the model were very much

Table 4 Logistic regression showing influence of independent variables on the adaptive capacity of small-scale farmers to climate change

\begin{tabular}{l|l|l|l|l|l|l}
\hline Independent variables & $\begin{array}{l}\text { Coefficients } \\
(\beta)\end{array}$ & $\begin{array}{l}\text { p- } \\
\text { level }\end{array}$ & $\begin{array}{l}\text { Std } \\
\text { error }\end{array}$ & Wald & df & $\begin{array}{l}\text { Odds ratio } \\
(\text { Exp } \beta)\end{array}$ \\
\hline Constant & $-1.961^{* * *}$ & 0.000 & 0.294 & 44.426 & 1 & 0.141 \\
\hline Number of farms & $0.271^{* *}$ & 0.003 & 0.092 & 8.690 & 1 & 1.311 \\
\hline Income of household & $1.821^{* * *}$ & 0.002 & 0.614 & 9.064 & 1 & 5.134 \\
\hline Information accessibility & $0.937^{*}$ & 0.087 & 0.548 & 2.929 & 1 & 2.553 \\
\hline Credit accessibility & $1.596^{* *}$ & 0.006 & 0.582 & 7.526 & 1 & 4.931 \\
\hline Land accessibility & $1.029^{* *}$ & 0.027 & 0.465 & 4.891 & 1 & 2.798 \\
\hline Log likelihood & 330.37 & & & & & \\
\hline Likelihood ratio $X^{2}$ & $145.84^{* * *}$ & 0.000 & & & & \\
\hline Nagelkerke $\mathrm{R}^{2}$ & 0.648 & & & & & \\
\hline $\begin{array}{l}\text { Number of cases correctly } \\
\text { classified }\end{array}$ & $80 \%$ & & & & & \\
\hline
\end{tabular}

${ }^{*},{ }^{* *},{ }^{* * *}$ Significant at $10 \%, 5 \%$, and $1 \%$ probability levels, respectively 
valid as far as determining the factors influencing small-scale farmers' adaptive capacity to climate change was concerned.

\section{Discussion}

\section{Variations in Climate Elements}

Extreme levels of variation in climate parameters (rainfall, temperature, and rainy days) have been recurrent in the north-west region of Cameroon in the past five decades which attests to climate variations and changes. Although other studies have shown the occurrence of climate variability in the north-west region of Cameroon (Innocent et al. 2016; Awazi 2018; Awazi and Tchamba 2018; Awazi et al. 2019), few studies in Cameroon have examined climatic variations using over five decades of climate data.

The chapter equally assessed the non-cause-effect and cause-effect relationship existing between climate parameters (temperature, rainy days, and rainfall) in the face of adverse climatic variations and changes. It was found that there is a very limited inverse relationship between rainfall and temperature as well as rainy days and temperature. Meanwhile a relatively strong direct relationship exists between rainfall and rainy days. This indicated that an interdependent relationship exists between rainfall and rainy days in the face of climate change. Studies carried out in other parts of the world by Chen and Wang (1995), Buishand and Brandsma (1999), Seleshi and Zanke (2004), Cong and Brady (2012), Berg et al. (2013), Olsson et al. (2015), Nkuna and Odiyo (2016), and Weng et al. (2017) have equally proven the existence of an interdependent relationship between climate parameters, although not in the context of climate change. By examining the relationship between climate parameters in the face of climate change, this chapter has filled a major knowledge gap.

\section{Adaptive Choices of Small-Scale Farmers Confronted with Climate Change}

It was found that most small-scale farmers practice agroforestry to enhance their adaptive capacity to climate change. Agroforestry practices therefore constitute a major adaptive choice for small-scale farmers. Most studies carried out in Africa (Easterling et al. 2007; Boko et al. 2007; Hassan and Nhemachena 2008; Gbetibouo 2009; FAO 2009b, 2010; Deressa et al. 2010) have merely shown that small-scale farmers adopt indigenous and non-indigenous adaptation strategies to combat the adversities of climate change. This chapter revealed that most small-scale farmers adopt agro-ecological farming practices like agroforestry to mitigate the adverse effects of climate change, thereby filling the knowledge gap. 


\section{Perceived Factors Affecting Farmers' Adaptive Capacity to Climate Change}

Small-scale farmers perceived several factors influencing their adaptive capacity. Among these factors, land accessibility, income of household, and the practice of agroforestry were perceived by small-scale farmers as the most important factors affecting their adaptive capacity to climate change. As reported by other scientific studies, small-scale farmers usually perceive a combination of factors influencing their adaptation to climate variations and changes. Most studies have assessed the different adaptation choices practiced by small-scale farmers to enhance adaptive capacity to climate change (McCarthy et al. 2004; Gbetibouo and Ringler 2009; Folke et al. 2010; World Bank 2013), with very limited literature dwelling on the adaptive capacity of small-scale farmers confronted with climate change. By examining small-scale farmers' perceptions of their adaptive capacity to climate change, this chapter has filled the knowledge gap. Although some studies (Gordon 2009; Gbetibouo 2009; Thorlakson 2011) have used conceptual and theoretical approaches to assess adaptive capacity to climate change, this chapter by applying the inferential statistical approach to examine small-scale farmers' adaptive capacity to climate change adversities has filled a major knowledge gap.

\section{Non-Cause-Effect and Cause-Effect Relationship Between Small-Scale Farmers' Adaptive Capacity to Climate Change and Independent/ Independent Variables}

A non-cause-effect relationship was found to exist between small-scale farmers' adaptive capacity and independent variables (institutional, environmental, and socioeconomic variables) like number of farms, household size, age of household head, income of household, level of education, gender, practice of agroforestry, information accessibility, credit accessibility, land accessibility, and access to extension services. Most studies undertaken across Africa and different parts of the world (McCarthy et al. 2004; Gbetibouo and Ringler 2009; Gordon 2009; Gbetibouo 2009; Folke et al. 2010; Thorlakson 2011; World Bank 2013; Awazi 2018; Awazi et al. 2019) mainly examined the non-cause-effect relationship existing between independent variables and small-scale farmers' adaptation choices to climate change. By unraveling the existence of a non-cause-effect relationship between adaptive capacity and different independent variables (institutional, environmental, and socioeconomic variables), this chapter has therefore filled a knowledge gap.

A direct cause-effect relationship was found to exist between small-scale farmers' adaptive capacity and five main independent variables (credit accessibility, information accessibility, income of household, number of farms, and land accessibility). These five independent variables could therefore be considered as very important in enhancing small-scale farmers' adaptive capacity to climate change. 
Thus, small-scale farmers with many farms are more adaptive to climate change which could be attributed to more yields obtained from these many farms which are consumed by the household and the excess sold to buy farm inputs. It could equally be that these farmers have more access to social and financial resources and/or better education which allows them to control more land and therefore enhanced adaptive capacity.

In the same light, small-scale farmers with better information accessibility are more adaptive to climate change than their counterparts with limited or no access which could be attributed to the fact that small-scale farmers with easy access to information are able to make plans into the future which helps them to adopt best practices.

Equally, small-scale farmers with more access to credit are more adaptive to climate change adversities than their fellow farmers with limited or no access to credit. This could be due to the fact that small-scale farmers with easy access to credit facilities are able to buy better farm inputs and can easily switch to best practices which act as a buffer to the adverse effects of climate change. Meanwhile small-scale farmers with little or no access to credit facilities are unable to buy good farm inputs and cannot switch to best practices on time which renders them weak and vulnerable in the face of climatic extremes.

Similarly, small-scale farmers with more access to land are better adaptive to climate change than their counterparts with limited or no land which can be attributed to the fact that land is an indispensable asset to any farmer, for it is the most important fixed asset, and without it, no farming activity can take place.

Some authors like Mccarthy et al. (2004), Gbetibouo (2009), Thorlakson (2011), and Awazi et al. (2019) have found the existence of cause-effect relationship between small-scale farmers' adaptation choices to climate change and different independent variables. Through the use of inferential statistics to examine the causeeffect relationship between adaptive capacity and different independent variables (institutional, socio-economic, and environmental factors), this chapter fills a major knowledge gap.

\section{Conclusion and Policy Implications}

Based on the findings of this chapter, it is clearly noticed that institutional, socioeconomic, and environmental factors are key determinants of small-scale farmers' adaptive capacity to climate change. The existence of a statistically significant direct cause-effect relationship between small-scale farmers' adaptive capacity and independent variables such as credit accessibility, information accessibility, land accessibility, income of household, and number of farms is testament to the vital role these livelihood capital assets play towards enhancing small-scale farmers' adaptive capacity to climate change. Thus, it is recommended that policy makers seeking to alleviate the plight of vulnerable small-scale farmers take these determinants of small-scale farmers' adaptive capacity into consideration when 
formulating policies geared towards enhancing small-scale farmers' adaptive capacity to climate change.

\section{References}

Adger WN, Agrawala S, Mirza MMQ, Conde C, O'Brien K, Puhlin J, Pulwarty R, Smit B, Takahashi K (2007) Assessment of adaptation practices, options, constraints and capacity. In climate change 2007: impacts, adaptation and vulnerability. Contribution of Working Group II to the fourth assessment of the IPCC, Palutikof JP, van der Linden PJ, Hansen CE (eds). Cambridge University Press, Cambridge. http://www.ipcc-wg2.gov/AR4/website/17.pdf

Aggarwal VRK, Mahajan PK, Negi YS, Bhardwaj SK (2015) Trend analysis of weather parameters and people perception in Kullu District of Western Himalayan region. Environ Ecol Res 3 (1):24-33. https://doi.org/10.13189/eer.2015.030104

Altieri MA, Koohafkan P (2008) Enduring farms: climate change, small-scales and traditional farming communities. Environment and development series 6. Third world network. Penang, Malaysia. http://www.fao.org/nr/water/docs/enduring_farms.pdf

Anderson J (2007) How much did property rights matter? Understanding food insecurity in Zimbabwe: a critique of Richardson. Afr Aff 106(425):681-690. https://doi.org/10.1093/afraf/ adm064.pdf

Atinkut B, Mebrat A (2016) Determinants of farmers' choice of adaptation to climate variability in Dera Woreda, South Gondar Zone, Ethiopia. Environ Syst Res 5:6. http://link.springer.com/ content/pdf/10.1186\%2Fs40068-015-0046-x.pdf

Awazi NP (2018) Adaptation options enhancing farmers' resilience to climate change. LAP LAMBERT Academic, 132 p. ISBN-10: 3330027940; ISBN-13: 978-3330027947

Awazi NP, Tchamba NM (2018) Determinants of small-scale farmers' adaptation decision to climate variability and change in the north-west region of Cameroon. Afr J Agric Res 13:534-543

Awazi NP, Tchamba NM (2019) Enhancing agricultural sustainability and productivity under changing climate conditions through improved agroforestry practices in small-scale farming systems in sub-Saharan Africa. Afr J Agric Res 14(7):379-388

Awazi NP, Tchamba NM, Tabi FO (2019) An assessment of adaptation options enhancing smallscale farmers' resilience to climate variability and change: case of Mbengwi Central subDivision, the north-west region of Cameroon. Afr J Agric Res 14(6):321-334

Awazi NP, Tchamba NM, Temgoua LF (2020) Enhancement of resilience to climate variability and change through agroforestry practices in smallholder farming systems in Cameroon. Agrofor Syst 94:687-705. https://doi.org/10.1007/s10457-019-00435-y

Azibo BR, Kimengsi JN (2015) Building an indigenous agro-pastoral adaptation framework to climate change in sub-Saharan Africa: experiences from the the north-west region of Cameroon. Procedia Environ Sci 29:126-127

Azibo BR, Kimengsi JN, Buchenrieder G (2016) Understanding and building on indigenous agropastoral adaptation strategies for climate change in sub-Saharan Africa: experiences from rural Cameroon. J Adv Agric 6(1):833-840. https://doi.org/10.24297/jaa.v6i1.5391

Belaineh L, Ayele Y, Bewket W (2013) Smallholder farmers' perceptions and adaptation to climate variability and change in Doba District, West Hararghe, Ethiopia. Asian J Empir Res 3(3):251265. http://www.aessweb.com/download.php?id=1838.pdf

Benhin J (2006) Climate change and South African agriculture: impacts and adaptation options. CEEPA discussion paper no 21, July 2006. https://www.weadapt.org/sites/weadapt.org/files/ legacy-new/knowledge-base/files/5370f181a5657504721bd5c21csouth-african-agriculture.pdf

Berg P, Moseley C, Haerter JO (2013) Strong increase in convective precipitation in response to higher temperatures. Nat Geosci 6:181-185 
Biermann F (2007) Earth system governance as a crosscutting theme of global change research. Global Environ Chang 17(2007):326-337. http://www.glogov.org/images/doc/Biermann\% 202007\%20GEC\%20Earth\%20System\%20Governance.pdf

Bishaw B, Neufeldt H, Mowo J, Abdelkadir A, Muriuki J, Dalle G, Assefa T, Guillozet K, Kassa H, Dawson IK, Luedeling E, Mbow C (2013) Farmers' strategies for adapting to and mitigating climate variability and change through agroforestry in Ethiopia and Kenya. Davis CM, Bernart B, Dmitriev A (eds). Forestry Communications Group, Oregon State University, Corvallis. http://international.oregonstate.edu/files/final_report_agroforestry_synthesis_paper_3_14_ 2013.pdf

Boissière M, Locatelli B, Sheil D, Padmanaba M, Sadjudin E (2013) Local perceptions of climate variability and change in tropical forests of Papua, Indonesia. Ecol Soc 18(4):13

Boko M, Niang I, Nyong A, Vogel C, Githeko A, Medany M, Osman-Elasha B, Tabo R, Yanda P (2007) Africa. Climate change 2007: impacts, adaptation and vulnerability. Contribution of Working Group II to the fourth assessment report of the Intergovernmental Panel on Climate Change, Parry ML, Canziani OF, Palutikof JP, van der Linden PJ, Hanson CE (eds). Cambridge University Press, Cambridge, UK, pp 433-467. https://www.ipcc.ch/pdf/assessment-report/ar4/ wg2/ar4-wg2-chapter9.pdf

Bryan E, Deressa TT, Gbetibouo GA, Ringler C (2009) Adaptation to climate change in Ethiopia and South Africa: options and constraints. Environ Sci Policy 12:413-426. https://www. researchgate.net/publication/222015072.pdf

Buishand TA, Brandsma T (1999) Dependence of precipitation on temperature at Florence and Livorno (Italy). Clim Res 12:53-63

CDCCP Synthesis Report (2009) Coping with drought and climate change project: case of the Chiredzi district of Zimbabwe. http://adaptation-undp.org/sites/default/files/downloads/cwd_ va_synthesis_report.pdf

Challinor AJ (2009) Developing adaptation options using climate and crop yield forecasting at seasonal to multi-decadal timescales. Environ Sci Policy 12(4):453-465. ISSN 0168-1923

Challinor AJ, Wheeler TR (2008) Crop yield reduction in the tropics under climate change: processes and uncertainties. Agric For Meteorol 148:343-356

Chanana-Nag N, Aggarwal PK (2018) Woman in agriculture, and climate risks: hotspots for development. Clim Chang. https://doi.org/10.1007/s10584-018-2233-Z

Chen Y-L, Wang J-J (1995) The effects of precipitation on the surface temperature and airflow over the island of Hawaii. Am Meteorol Soc 123:681-694

Cong R-G, Brady M (2012) The interdependence between rainfall and temperature: copula analyses. Sci World J 2012:405675, 11 pages. https://doi.org/10.1100/2012/405675

De Wit M (2006) Measuring the economic impacts of climate change on crop farming in Africa. Climate change and African agriculture policy note no 8. CEEPA, University of Pretoria, Pretoria

Deressa T, Hassan RM, Alemu T, Yesuf M, Ringler C (2008) Analyzing the determinants of farmers' choice of adaptation methods and perceptions of climate change in the Nile Basin of Ethiopia. IFPRI discussion paper 00798. International Food Policy Research Institute, Washington, DC, 26 p. https://core.ac.uk/download/pdf/6337745.pdf

Deressa TT, Hassan RM, Ringler C, Alemu T, Yesuf M (2009) Determinants of farmers' choice of adaptation methods to climate change in the Nile Basin of Ethiopia. Glob Environ Chang 19:248-255. http://www.sciencedirect.com/science/article/pii/S0959378009000156.pdf

Deressa TT, Ringler C, Hassan RM (2010) Factors affecting the choices of coping strategies for climate extremes: the case of farmers in the Nile Basin of Ethiopia. IFPRI discussion paper no. 01032. International Food Policy Research Institute, Washington, DC, 25 pp. http://ebrary.ifpri. org/cdm/ref/collection/p15738coll2/id/5198.pdf

Deressa TT, Hassan RM, Ringler C (2011) Perception of and adaptation to climate change by farmers in the Nile Basin of Ethiopia. J Agric Sci 149:23-31

Di Falco S, Veronesi M, Yesuf M (2011) Does adaptation to climate change provide food security? A micro-perspective from Ethiopia, am. J Agric Econ 93(3):829-846. https://doi.org/10.1093/ ajae/aar006 
Easterling WE, Aggarwal PK, Batima P, Brander KM, Erda L, Howden SMA, Kirilenko A, Morton J, Soussana JF, Schmidhuber J, Tubiello FN (2007) Food, fibre and forest products. Climate Change 2007: Impacts, adaptation and vulnerability. Contribution of Working Group II to the fourth assessment report of the Intergovernmental Panel on Climate Change, Parry ML, Canziani OF, Palutikof JP, van der Linden PJ, Hanson CE (eds). Cambridge University Press, Cambridge, UK, pp 273-313. https://www.ipcc.ch/pdf/assessment-report/ar4/wg2/ar4-wg2chapter5.pdf

FAO, IFAD, UNICEF, WFP, WHO (2018) The state of food security and nutrition in the world 2018. Building climate resilience for food security and nutrition. FAO, Rome. Licence: CC BYNC-SA 3.0 IGO

Folke C, Carpenter SR, Walker B, Scheffer M, Chapin T, Rockström J (2010) Resilience thinking: integrating resilience, adaptability and transformability. Ecol Soc 15(4):20. [Online]. URL: http://www.ecologyandsociety.org/vol15/iss4/art20/.pdf

Food and Agriculture Organization (FAO) (2006) Livelihood Adaptation to climate variability and change in drought-prone areas of Bangladesh, Rome, p 97. ftp://ftp.fao.org/docrep/fao/009/ a0820e/a0820e.pdf

Food and Agriculture Organization (FAO) (2008) Climate change adaptation and mitigation in the food and agriculture sector. High Level Conference on World Food Security - background paper HLC/08/BAK/1. ftp://ftp.fao.org/docrep/fao/meeting/013/ai782e.pdf

Food and Agriculture Organization (FAO) (2009a) Profile for climate change, Rome, 28 pp. ftp:// ftp.fao.org/docrep/fao/012/i1323e/i1323e00.pdf

Food and Agriculture Organization (FAO) (2009b) Climate change and agriculture policies; How to mainstream climate change adaptation and mitigation into agriculture policies, Rome, $76 \mathrm{pp}$. http:// www.fao.org/fileadmin/templates/ex_act/pdf/Climate_change_and_agriculture_policies_EN.pdf

Food and Agriculture Organization (FAO) (2010a) Homestead gardens in Bangladesh. Technology for agriculture. Proven technologies for small holders. http://www.fao.org/teca/content/ homestead-gardens-bangladesh.pdf. Accessed 26 October 2014

Food and Agriculture Organization (FAO) (2010b) Incorporation of tree management into land management in Jamaica - guinea grass mulching. Technology for agriculture. Proven technologies for small holders. http://www.fao.org/teca/content/incorporation-tree-management-landmanagement-jamaica- $\% \mathrm{C} 2 \%$ BF-guinea-grass-mulching.pdf

Food and Agriculture Organization (FAO) (2010c) Collaborative change; a communication framework for climate change adaptation and food security, Rome, $47 \mathrm{pp}$. http://www.fao.org/docrep/ 012/i1533e/i1533e00.pdf

Food and Agriculture Organization (FAO) (2011) Framework programme on climate change adaptation, Fao-Adapt. http://www.fao.org/docrep/014/i2316e/i2316e00.pdf

Food and Agriculture Organization (FAO) (2016) Climate change and food security: risks and responses. http://www.fao.org/3/a-i5188e.pdf

Gbetibouo AG (2009) Understanding farmers' perceptions and adaptations to climate change and variability: the case of the Limpopo Basin, South Africa. IFPRI discussion paper no. 00849. International Food Policy Research Institute, Washington, DC, 36 pp. http://www.ifpri.org/ publication/understanding-farmers-perceptions-and-adaptations-climate-change-and-variability.pdf

Gbetibouo GA, Ringler C (2009) Mapping South African farming sector vulnerability to climate change and variability; a sub national assessment. IFPRI discussion paper 00885. http://www. ifpri.org/publication/mapping-south-african-farming-sector-vulnerability-climate-change-andvariability.pdf

Gordon CR (2009) The science of climate change in Africa: impacts and adaptation, Grantham Institute for Climate Change, discussion paper $\mathrm{N}^{\mathrm{O}}$ 1. Imperial College London, https:// workspace.imperial.ac.uk/climatechange/public/pdfs/discussion_papers/Grantham_Institue_The_science_of_climate_change_in_Africa.pdf

Hadgu G, Tesfaye K, Mamo G, Kassa B (2015) Farmers' climate change adaptation options and their determinants in the Tigray region, northern Ethiopia. Afr J Agric Res 10(9):956-964. http://www.academicjournals.org/journal/AJAR/article-full-text/9A1563251045.pdf 
Hassan R, Nhemachena C (2008) Determinants of African farmers' strategies for adapting to climate change: multinomial choice analysis. Afr J Agric Resour Econ 2(1):83-104. http:// ageconsearch.umn.edu/bitstream/56969/2/0201\%20Nhemachena $\% 20 \% 26 \% 20 \mathrm{Hassan}_{0} \% 20-\%$ $2026 \% 20$ may.pdf

Herrero M, Ringler C, van de Steeg J, Thornton P, Zhu T, Bryan E, Omolo A, Koo J, Notenbaert A (2010) Climate variability and climate change: impacts on Kenyan agriculture. International Food Policy Research Institute, Washington, DC. https://cgspace.cgiar.org/bitstream/handle/ 10568/3840/climateVariability.pdf

Innocent NM, Bitondo D, Azibo BR (2016) Climate variability and change in the Bamenda highlands of the north-west region of Cameroon: perceptions, impacts and coping mechanisms.

Br J Appl Sci Technol 12(5):1-18

Intergovernmental Panel on Climate Change (IPCC) (2007) Climate change 2007: impacts, adaptation and vulnerability. Summary for policymakers, IPCC AR4 WGII. Cambridge University Press, Cambridge, UK. https:/www.ipcc.ch/pdf/assessment-report/ar4/wg2/ar4-wg2-spm.pdf

International Fund for Agricultural Development (IFAD) (2012) Sustainable small-scale agriculture: feeding the world, protecting the planet. Proceedings of the Governing Council Events. In conjunction with the thirty-fifth session of IFAD's Governing Council, February 2012. https:// www.ifad.org/documents/10180/6d13a7a0-8c57-42ec-9b01-856f0e994054.pdf

IPCC, (2014). Climate change 2014: synthesis report. Contribution of working groups I, II and III to the fifth assessment report of the Intergovernmental Panel on Climate Change [Core Writing Team, Pachauri RK, Meyer LA (eds)]. IPCC, Geneva, 151 pp. https://www.ipcc.ch/pdf/ assessment-report/ar5/syr/SYR_AR5_FINAL_full.pdf

IPCC (2018) Summary for policymakers. In: Masson-Delmotte V, Zhai P, Pörtner HO, Roberts D, Skea J, Shukla PR, Pirani A, Moufouma-Okia W, Péan C, Pidcock R, Connors S, Matthews JBR, Chen Y, Zhou X, Gomis MI, Lonnoy E, Maycock T, Tignor M, Waterfield T (eds) Global warming of $1.5^{\circ} \mathrm{C}$. An IPCC special report on the impacts of global warming of $1.5^{\circ} \mathrm{C}$ above pre-industrial levels and related global greenhouse gas emission pathways, in the context of strengthening the global response to the threat of climate change, sustainable development, and efforts to eradicate poverty. World Meteorological Organization, Geneva, $32 \mathrm{pp}$

Ishaya S, Abaje IB (2008) Indigenous people's perception on climate change and adaptation strategies in Jema'a local government area of Kaduna state. Nigeria J Geogr Reg Plann 1 (8):138-143

Juana JS, Zibanani K, Okurut FN (2013) Farmers' perceptions and adaptations to climate change in sub-Sahara Africa: a synthesis of empirical studies and implications for public policy in African agriculture. J Agric Sci 5:121-135

Kabir KH, Billah MM, Sarker MA, Miah MAM (2015) Adaptation of farming practices by smallscale farmers in response to climate change. J Agric Ext Rural Dev 7(2):33-40. http://www. academicjournals.org/journal/JAERD/article-full-text/EB533A551012

Kurukulasuriya P, Mendelsohn R (2007) Crop selection: adapting to climate change in Africa. World Bank policy research working paper 4307, Sustainable Rural and Urban Development Team. http://library1.nida.ac.th/worldbankf/fulltext/wps04307.pdf

Kuwornu MKJ, Hassan MR, Etwire MP, Osei-Owusu Y (2013) Determinants of choice of indigenous climate related strategies by small-scale farmers in northern Ghana. British Journal of Environment and Climate Change 3(2):172-187. http://www.sciencedomain.org/reviewhistory.php? iid $=251 \&$ id $=10$ \&aid $=1785$.pdf

Maddison D (2006) The perception of and adaptation to climate change in Africa. Centre for Applied Environmental Economics and Policy in Africa (CEEPA). Discussion paper no 10. CEEPA, University of Pretoria, Pretoria. http://www.ceepa.co.za/uploads/files/CDP10.pdf

Maddison D (2007) Perception and adaptation to climate change in Africa. Policy research working paper, 4308

Majule AE, Ngongondo C, Kallanda-Sabola M, Lamboll R, Stathers T, Liwenga E, Ngana OJ (2008) Strengthening local agricultural innovation systems in less and more favoured areas of Tanzania and Malawi to adapt to climate change and variability: perceptions. Impacts, 
vulnerability and adaptation. Res. Abstracts. Issue Number 3: Sokoine University of Agric.: ISBN: 9987-38-9

Mary AL, Majule AE (2009) Impacts of climate change, variability and adaptation strategies on agriculture in semi arid areas of Tanzania: the case of Manyoni District in Singida region, Tanzania. Afr J Environ Sci Technol 3(8):206-218

Mbow C, Smith P, Skole D, Duguma L, Bustamante M (2013) Achieving mitigation and adaptation to climate change through sustainable agroforestry practices in Africa. Curr Opin Environ Sustain 6:8-14. 2014. http://ac.els-cdn.com/S1877343513001255/1-s2.0-S1877343513001255-main. pdf? tid $=84$ bce 8 a4 - ea32-11e5-ab6e-00000aab0 f6b\&acdnat $=1457994020$ 73ea11926686e4ef3ccb03abe1829c42

Mbow C, Noordwijk MV, Luedeling E, Neufeldt H, Minang PA, Kowero G (2014) Agroforestry solutions to address food security and climate change challenges in Africa. Curr Opin Environ Sustain 6:61-67. http://ac.els-cdn.com/S1877343513001449/1-s2.0-S1877343513001449main.pdf? tid $=45 \mathrm{e} 8 \mathrm{adc} 0-\mathrm{ea} 32-11 \mathrm{e} 5-9 \mathrm{~b} 7 \mathrm{f}-00000 \mathrm{aacb} 35 \mathrm{f} \& \mathrm{acdnat}=1457993914$ 1 fcfbc75960e 7 afcce $80 \mathrm{~d} 0 \mathrm{f} 1082 \mathrm{f} 300 \mathrm{e}$

McCarthy J, Martello J, Marybeth L (2004) Climate change in the context of multiple stressors and resilience. ACIA scientific report. Cambridge University Press, pp 945-983. www.acia.uaf.edu/ PDFs/ACIA_Science_Chapters_Final/ACIA_Ch17_Final.pdf

Mersha AA, Laerhoven FV (2016) A gender approach to understanding the differentiated impact of barriers to adaptation: responses to climate change in rural Ethiopia. Reg Environ Chang. https:// doi.org/10.1007/s10113-015-0921-z

Mertz O, Mbow C, Reenberg A, Diouf A (2009) Farmers' perceptions of climate change and agricultural adaptation strategies in rural Sahel. Environ Manag 43(5):804-816

Molua EL (2006) Climate trends in Cameroon: implications for agricultural management. Clim Res 30:255-262

Molua EL (2008) Turning up the heat on African agriculture: the impact of climate change on Cameroon's agriculture. AfJARE 2(1):-20. http://ageconsearch.umn.edu/bitstream/56967/2/ 0201\%20si\%20malua\%20-\%2026\%20may.pdf

Molua EL, Lambi CM (2006) The economic impact of climate change on agriculture in Cameroon. In CEEPA discussion paper no. 17

Mortimore MJ, Adams WM (2001) Farmer adaptation, change and crisis in the Sahel. Glob Environ Chang 11:49-57

Mtambanengwe F, Mapfumo P, Chikowo R, Chamboko T (2012) Climate change and variability: small-scale farming communities in Zimbabwe portray a varied understanding. African Crop Science Journal 20(Suppl 2):227-241. http://www.bioline.org.br/pdf?cs12041pdf

Mulenga BP, Wineman A (2014) Climate trends and farmers' perceptions of climate change in Zambia. Working paper no. 86 September 2014. Indaba Agricultural Policy Research Institute (IAPRI) Lusaka, Zambia. http://fsg.afre.msu.edu/zambia/wp86_rev.pdf

National Academy of Sciences (NAS) and the Royal Society (RS) (2014) Climate change, evidence and causes. An overview from the Royal Society and an the United States Academy of Sciences. $\mathrm{http} / / / \mathrm{dels}$.nas.edu/resources/static-assets/exec-office-other/climate-change-full.pdf

Nhemachena C, Hassan R (2007) Micro-level analysis of farmers' adaptation to climate change in southern Africa. IFPRI discussion paper no. 00714. International Food Policy Research Institute, Washington, DC, $30 \mathrm{pp}$. https://ipcc-wg2.gov/njlite_download2.php?id=8035pdf

Niles MT, Salerno JD (2018) A cross-country analysis of climate shocks and small-scale food insecurity. PLoS One 13(2):e0192928. https://doi.org/10.1371/journal.pone.0192928

Nkuna TR, Odiyo JO (2016) The relationship between temperature and rainfall variability in the Levubu sub-catchment, South Africa. Int J Environ Sci 1:66-75. http://iaras.org/iaras/journals/ijes

Nyanga PH, Johnsen FH, Aune JB, Kalinda TH (2011) Small-scale farmers' perceptions of climate change and conservation agriculture: evidence from Zambia. J Sustain Dev 4(4):73-85

Nzeadibe TC, Egbule CL, Chukwuone NA, Agwu AE, Agu VC (2012) Indigenous innovations for climate change adaptation in the Niger Delta region of Nigeria. Environ Dev Sustain 14(6):901-914 
Olsson T, Jakkila J, Veijalainen N, Backman L, Kaurola J, Vehviläinen B (2015) Impacts of climate change on temperature, precipitation and hydrology in Finland - studies using bias corrected Regional Climate Model data. Hydrol Earth Syst Sci 19:3217-3238. https://oi.org/10.5194/ hess-19-3217-2015

Rao KPC, Ndegwa WG, Kizito K, Oyoo A (2011) Climate variability and change: farmer perceptions and understanding of intra-seasonal variability in rainfall and associated risk in semi-arid Kenya. Exp Agric 47:267-291. https://doi.org/10.1017/S0014479710000918

Rurinda JP (2014) Vulnerability and adaptation to climate variability and change in small-scale farming systems in Zimbabwe. Thesis submitted in fulfillment of the requirements for the Degree of Doctor at Wageningen University, and publicly defended on Tuesday 10 June 2014 at 11 a.m. in the Aula. http://edepot.wur.nl/305159pdf

Rurinda JP, Mapfumo P, Van Wijk MT, Mtambanengwe F, Rufino MC, Chikowo R, Giller KE (2014) Sources of vulnerability to a variable and changing climate among small-scale households in Zimbabwe: a participatory analysis. Clim Risk Manag 3:65-78

Seleshi Y, Zanke U (2004) Recent changes in rainfall and rainy days in Ethiopia. Int J Climatol 24:973-983

Tabi FO, Adiku SGK, Kwadwo O, Nhamo N, Omoko M, Atika E, Mayebi A (2012) Perceptions of rain-fed lowland rice farmers on climate change, their vulnerability, and adaptation strategies in the Volta region of Ghana. Technol Innov Dev. https://doi.org/10.1007/978-2-8178-0268-8_12

Tambo JA, Abdoulaye T (2012) Climate change and agricultural technology adoption: the case of drought tolerant maize in rural Nigeria. Mitig Adapt Strateg Glob Chang 17:277-292. http:// link.springer.com/article/10.1007\%2Fs11027-011-9325-7htlm

Temesgen D, Yehualashet H, Rajan DS (2014) Climate change adaptation of small-scale farmers in south eastern Ethiopia. J Agric Ext Rural Dev 6(11):354-366

Tessema YA, Aweke CS, Endris GS (2013) Understanding the process of adaptation to climate change by small-scale farmers: the case of East Hararghe zone, Ethiopia. Agric Food Econ 1:13. http://agrifoodecon.springeropen.com/articles/10.1186/2193-7532-1-13

The Royal Society (2010). Climate change: a summary of the science, September 2010. https:// royalsociety.org/ /media/Royal_Society_Content/policy/publications/2010/4294972962.pdf

Thorlakson T (2011) Reducing subsistence farmers' vulnerability to climate change: the potential contributions of agroforestry in western Kenya, occasional paper 16. World Agroforestry Centre, Nairobi. http://www.worldagroforestry.org/downloads/Publications/PDFS/OP11183. pdf

Tingem M, Rivington M, Bellocchi G (2009) Adaptation assessments for crop production in response to climate change in Cameroon. Agron Sustain Dev 29(2):247-256. Springer Verlag (Germany), 2009. http://link.springer.com/article/10.1051\%2Fagro\%3A2008053

Weng F, Zhang W, Wu X, Xu X, Ding Y, Li G, Liu Z, Wang S (2017) Impact of low-temperature, overcast and rainy weather during the reproductive growth stage on lodging resistance of rice. Sci Rep 7:1-9

World Bank (2013) Turn down the heat: climate extremes, regional impacts, and the case for resilience. A report for the World Bank by the Potsdam Institute for Climate Impact Research and Climate Analytics. World Bank, Washington, DC. License: Creative Commons Attribution - Non Commercial-NoDerivatives3.0 Unported license (CC BY-NC-ND 3.0). http://www. worldbank.org/content/dam/Worldbank/document/Full_Report_Vol_2_Turn_Down_The_ Heat_\%20Climate_Extremes_Regional_Impacts_Case_for_Resilience_Print\%20version_ FINAL.pdf

Yaro JW (2013) The perception of and adaptation to climate variability/change in Ghana by smallscale and commercial farmers. Reg Environ Chang 13(6):1259-1272

Zivanomoyo J, Mukarati J (2012) Determinants of choice of crop variety as climate change adaptation option in arid regions of Zimbabwe. Russ J Agric Socio-Econ Sci 3(15). http:// www.rjoas.com/issue-2013-03/i015_article_2013_08.pdf 
Open Access This chapter is licensed under the terms of the Creative Commons Attribution 4.0 International License (http://creativecommons.org/licenses/by/4.0/), which permits use, sharing, adaptation, distribution and reproduction in any medium or format, as long as you give appropriate credit to the original author(s) and the source, provide a link to the Creative Commons license and indicate if changes were made.

The images or other third party material in this chapter are included in the chapter's Creative Commons license, unless indicated otherwise in a credit line to the material. If material is not included in the chapter's Creative Commons license and your intended use is not permitted by statutory regulation or exceeds the permitted use, you will need to obtain permission directly from the copyright holder.

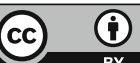

